\title{
Potentials, Utilization, and Bioengineering of Plant Growth-Promoting Methylobacterium for Sustainable Agriculture
}

\author{
Cong Zhang ${ }^{1,+}$, Meng-Ying Wang ${ }^{1,+}$, Naeem Khan ${ }^{2}{ }^{\mathbb{D}}$, Ling-Ling Tan ${ }^{1, *}$ and Song Yang ${ }^{1,3, *}$ \\ 1 School of Life Sciences, Shandong Province Key Laboratory of Applied Mycology, Qingdao Agricultural \\ University, Qingdao 266000, China; zhangcong19890409@163.com (C.Z.); \\ wangmengying_96@163.com (M.-Y.W.) \\ 2 Department of Agronomy, Institute of Food and Agricultural Sciences, University of Florida, Gainesville, \\ FL 32611, USA; naeemkhan@ufl.edu \\ 3 Key Laboratory of Systems Bioengineering, Ministry of Education, Tianjin University, Tianjin 300000, China \\ * Correspondence: Tanlingling80@163.com (L.-L.T.); yangsong1209@163.com (S.Y.) \\ + These authors equally contributed to this work.
}

check for updates

Citation: Zhang, C.; Wang, M.-Y.; Khan, N.; Tan, L.-L.; Yang, S.

Potentials, Utilization, and

Bioengineering of Plant

Growth-Promoting Methylobacterium for Sustainable Agriculture.

Sustainability 2021, 13, 3941. https:/ /

doi.org/10.3390/su13073941

Academic Editor:

Muhammad Naveed

Received: 19 February 2021

Accepted: 24 March 2021

Published: 02 April 2021

Publisher's Note: MDPI stays neutral with regard to jurisdictional claims in published maps and institutional affiliations.

Copyright: (c) 2021 by the authors. Licensee MDPI, Basel, Switzerland. This article is an open access article distributed under the terms and conditions of the Creative Commons Attribution (CC BY) license (https:/ / creativecommons.org/licenses/by/ $4.0 /)$

\begin{abstract}
Plant growth-promoting bacteria (PGPB) have great potential to provide economical and sustainable solutions to current agricultural challenges. The Methylobacteria which are frequently present in the phyllosphere can promote plant growth and development. The Methylobacterium genus is composed mostly of pink-pigmented facultative methylotrophic bacteria, utilizing organic one-carbon compounds as the sole carbon and energy source for growth. Methylobacterium spp. have been isolated from diverse environments, especially from the surface of plants, because they can oxidize and assimilate methanol released by plant leaves as a byproduct of pectin formation during cell wall synthesis. Members of the Methylobacterium genus are good candidates as PGPB due to their positive impact on plant health and growth; they provide nutrients to plants, modulate phytohormone levels, and protect plants against pathogens. In this paper, interactions between Methylobacterium spp. and plants and how the bacteria promote crop growth is reviewed. Moreover, the following examples of how to engineer microbiomes of plants using plant-growth-promoting Methylobacterium are discussed in the present review: introducing external Methylobacterium spp. to plants, introducing functional genes or clusters to resident Methylobacterium spp. of crops, and enhancing the abilities of Methylobacterium spp. to promote plant growth by random mutation, acclimation, and engineering.
\end{abstract}

Keywords: Methylobacterium; biofertilizer; biostimulator; biocontrol; plant growth promoting bacteria; microbiome engineering

\section{Introduction}

The population is increasing rapidly on Earth, reaching 7.8 billion and is estimated to exceed 9 billion by 2050 (data according to the United Nations Department of Economic and Social Affairs). How to feed the increased population is a major challenge for agriculture. To solve this problem, global food production needs to be increased by $70 \%$ to meet demands by 2050 [1]. Therefore, agriculture must be developed in a more sustainable and affordable way. In recent years, chemical fertilizers and pesticides have been used intensively to increase crop yields [2]. Neither chemical fertilizers nor chemical pesticides have been found to be environmentally friendly or ecologically sustainable. Moreover, the application of chemical fertilizers or pesticides always pollutes the surrounding water and air [3]. Chemical fertilizers and pesticides may destroy the soil nutrient balance, lead to poor soil quality, and give rise to a variety of plant diseases [4,5]. Thus, substitutes for chemical fertilizers and pesticides are needed to increase crop yields in a sustainable way. Microbial agents that promote plant growth and yield have the potential to be utilized in agriculture in the future. 
Plant microbiomes, which include microbial communities that live, thrive, and interact with tissues such as leaves, flowers, roots, shoots, and seeds, could improve growth, health, and production of plants and protect plants from potential pathogens [6]. Plant microbiomes are composed of bacteria, fungi, and archaea [7,8], among which bacterial microbiomes are regarded to play important roles in promoting plant growth, and could be used in agriculture as microbial agents (https://www.newleafsym.com/ (accessed on 26 March 2021)). The Methylobacterium genus is one of the major components of plant microbiomes. The diversity of the Methylobacterium community in soil is influenced by plants growth [9]. The Methylobacterium genus was proposed in 1976 and is composed of Gram-negative bacteria belonging to the $\alpha$-proteobacteria family. Bacteria of the Methylobacterium genus generally have pink pigmentation due to carotenoid synthesis. They are able to utilize organic one-carbon compounds (Figure 1), such as formate, formaldehyde, methanol, and methylamine, as the sole carbon and energy source for growing. Most members of the Methylobacterium genus are denoted as "pink-pigmented facultative methylotrophs" (PPFM).

(A)

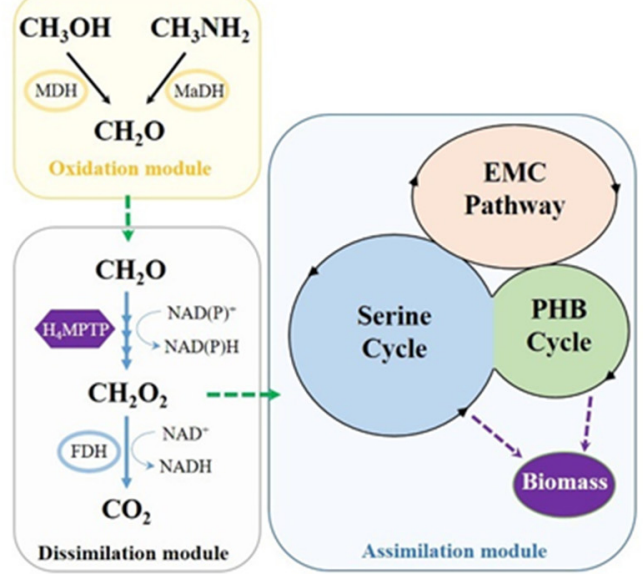

(B)

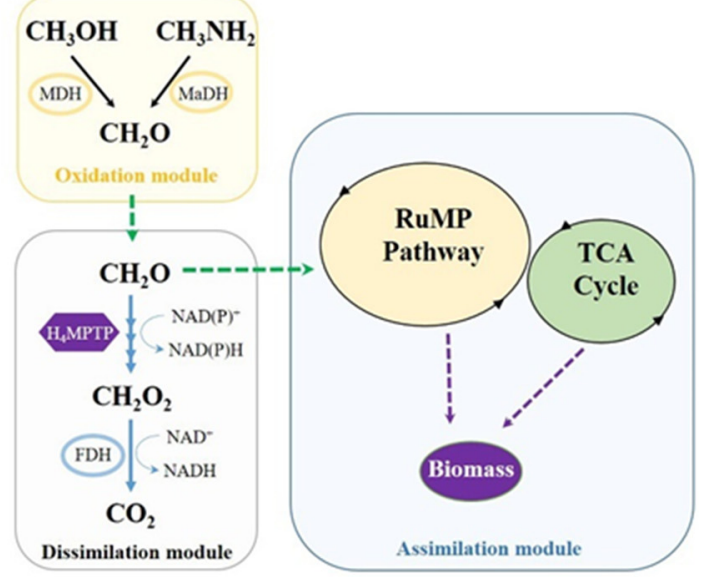

Figure 1. Metabolic modules of $\alpha$-proteobacteria (A) and $\gamma$-proteobacteria (B) methylotrophs. For alpha-proteobacteria methylotrophs, it has three interlocked metabolic cycles, that is, the serine cycle, the ethylmalonyl-CoA (EMC) pathway, and the poly-3-hydroxybutyrate (PHB) cycle for $\mathrm{C} 1$ assimilation. The overlapped intermediates have been shown. For gamma-proteobacteria methylotrophs, the intermediate pyruvate generated from ribulose monophosphate (RuMP) pathway is decarboxylized into acetyl-CoA, which then enters the tricarboxylic acid (TCA) cycle.

To date, 60 species have been classified in the Methylobacterium genus (https: / /www. bacterio.net/genus/methylobacterium (accessed on 26 March 2021)), and 11 species have been classified into a new genus, Methylorubrum. As all members of the Methylorubrum genus belonged to the Methylobacterium genus before 2018, we discuss them together as Methylobacterium spp. Some members of the Methylobacterium genus dominate the phyllosphere for some plants, especially crops such as rice, clover, and soybean [8]. For example, the strains of $M$. extorquens PA1 and M. oryzae were isolated from the phyllosphere of Arabidopsis thaliana and rice [10,11]. Other members such as M. nodulans and M. mesophilicum can inhabit roots, shoots, seeds, and seedlings [12]. Many members including $M$. oryzae, $M$. nodulans, $M$. radiotolerans, and some unclassified species of the Methylobacterium genus have been reported to significantly promote plant growth [13-15] (Table 1). Accordingly, Methylobacterium spp. are applied, though not widely, in agriculture to increase crop yields in food crops such as wheat, corn, peanut, and tomato ( https: / / www.newleafsym.com/ (accessed on 26 March 2021)). Here, we mainly review how Methylobacterium spp. inhabit plants and promote plant growth, as well as the utilization and perspectives of Methylobacterium spp. as microbial agents. 
Table 1. Effects of members from the Methylobacterium genus on host plants.

\begin{tabular}{ccr}
\hline Species Name & Host Plants & Effects on Host Plants \\
\hline M. nodulans & Crotalaria & providing nitrogen; decreasing levels of ethylene [12,16,17] \\
\hline M. oryzae & Rice & increasing plant cytokinin levels; solubilizing phosphate [13,18-20] \\
\hline M. extorquens & Pine; Arabidopsis; Brassia & inducing the expression of host defense genes [21,22] \\
\hline M. mesophilicum & Sugarcane & increasing plant cytokinin levels [23] \\
\hline M. radiotolerans & Brassia; Combretaceae & providing nitrogen; exhibited high antibacterial and antifungal activity; \\
decreasing levels of ethylene [24,25]
\end{tabular}

\section{Interactions between Methylobacteria and Plants}

Generally, bacteria interacting with plants act as endophytes or epiphytes. Endophytic microorganisms inhabit the plant tissue without causing damage or forming any visible external structures to the host [29]. Epiphytes, on the contrary, are those bacteria that live on the surface of plants. Methylobacterium spp. interact with plants, usually as both endophytes and epiphytes. Methylobacterium spp. acts as an important endophyte in sugarcane and Jatropha curcas and play an important role in the growth and yield of these crops $[23,26]$. Other members of the genus such as M. extorquens PA1, M. oryzae, and M. nodulans were reported to live on the surface of plants in both the phyllosphere and rhizosphere regions $[10,20,30]$. The rhizosphere, because it comprises the area in the soil around plant roots, is friendlier than the phyllosphere for microorganisms to inhabit. Some species, such as $M$. nodulans, inhabiting the rhizosphere could fix nitrogen and promote plant growth [17]. Microorganisms inhabiting the phyllosphere face harsh environments to survive, including a lack of carbon or energy sources, direct exposure to the rays of the sun, and drought stress.

Although microorganisms in the phyllosphere are less frequently studied than those inhabiting the rhizosphere, in recent decades, as "OMICS" technologies have developed, microorganisms in the phyllosphere have gradually become known. PCR amplification of 16S rRNA genes followed by sequencing of clone libraries and amplicon pyrosequencing have been used to identify bacterial communities in the phyllosphere of Quercus macrocarpa, soybean, Tamarix, and some tropical rainforest trees and crops as well [31,32]. Methylobacteria are detected in the phyllosphere of most plants and are found to dominate the phyllosphere of plants such as rice, clover, soybean, and Arabidopsis thaliana, while other $\alpha$-proteobacteria including Sphingomonas, Pantoea, Kocuria, Microbacterium, and Curtobacterium genera are also frequently detected [8]. Proteomic and transcriptomic approaches have been used to study adaptation to the phyllosphere of M. extorquens [21]. Previous reports showed that methanol released from stomata through cell expansion attracted Methylobacteria, which used methanol as the sole carbon source [33]. Compared with the rhizosphere, Methylobacterium spp. are found to prefer inhabiting the phyllosphere [34]. Methylobacterium spp. produce UV-absorbing compounds that might help the bacteria and plants survive in a phyllosphere exposed to direct sunlight [35]. Members of the Methylobacterium genus including M. extorquens and M. mesophilicum, form biofilms on the plant surface and in tissues, which might help the bacteria survive in plants [36]. When inhabiting plants in the phyllosphere, some strains upregulate the transcription of genes related to methanol utilization to survive in nutrient-limited environments $[37,38]$. During plant colonization, a methanol dehydrogenase-like protein XoxF was upregulated significantly; proteins involved in formate oxidation, such as Fdh1 and Fdh3, were also 
produced more extensively [39]. Strains isolated from plants also show features that help them adapt to the host environment. For example, the $M$. extorquens strain PA1 isolated from $A$. thaliana shows similar genome information to that of the well characterized strain AM1, including genome size, GC contents, and genes involved in methanol utilization. However, these strains showed different growth rates when using different substrates, which might reflect adaptation to the niche from which they were isolated [39]. Moreover, proteomic and transcriptomic studies indicate that, compared with M. extorquens strains cultured in the laboratory, those inhabiting the phyllosphere showed obvious adaptation [39]. Some proteins are upregulated in the phyllosphere, especially PhyR, a phyllosphere regulator responsible for general stress [21]. The expression of genes related to anoxygenic photosynthesis was also upregulated, indicating that $M$. extorquens might utilize solar energy to compensate for ATP consumption during growth in the poor carbon source of the phyllosphere [39].

Methylobacterium also provide a major bacterial endophyte community in some plants such as Brassica, sugarcane, and J. curcas [26,36,40]. Methylobacterium spp. were found to account for $69.1 \%$ of endophytic bacterial isolates in the leaves of $J$. curcas. In sugarcane, Methylobacterium spp. are important endophytes considered responsible for increased seed germination, leaf area, plant height, and number of internodes [36]. These effects might be due to the synthesis of biologically active metabolites such as cytokinins and auxins by Methylobacterium spp. Methylobacterium spp. including M. fujisawaense, M. phyllosphaerae, M. oryzae, and M. extorquens constituted $56 \%$ of the bacteria isolated from several Brassian species. M. fujisawaense and M. phyllosphaerae increased the oilseed fresh weights by $100 \%$ and $27 \%$, respectively [40].

Methylobacterial community composition interacting with plants is influenced by many factors including sites, environments, and plant species. Knief et al. [32] studied the influence of the factor site, host plant species, time, and presence of other phyllosphere bacteria on Methylobacterial community composition and population size, finding that nearly half of the variation in the Methylobacterial community composition could be explained by site and species, with some members of the communities being host-plant specific [41]. In the phyllosphere of some temperate trees, evolutionary associations between groups of bacteria and host species were significant, and bacterial community structure was determined mainly by host species [42].

\section{Insights into the Plant Growth Promoting Mechanisms Employed by Methylobacteria}

The mechanisms used by Methylobacterium spp. to promote plant growth have been studied in recent years (Figure 2). Generally, Methylobacterium spp. promote plant growth by the following mechanisms:

\subsection{Nutrient Acquisition}

Members of the Methylobacterium genus provide important nutrients to plants as they fix nitrogen and solubilize phosphorus and iron. Methylobacteria possess great potential to be utilized as a biofertilizer in agriculture. Many agricultural soils lack one or more nutrients and are not optimal for crop growth [43]. To obtain higher crop yields, chemical fertilizers including nitrogen, iron, or phosphorus are frequently used. Nearly half of the world's food supply depends on chemical nitrogen fertilizers, which might emit greenhouse gas and pollute water during production of the chemical fertilizers. M. nodulans isolated from root nodules of Crotalaria fixed nitrogen by increasing the number of nodules on the roots of legume plants and promoted their growth [30]. Methylobacterium sp. 4-46 and Methylobacterium sp. L2-4, which are closely related to M. radiotolerans, have also been reported to be involved in nitrogen fixation [44]. In addition, some Methylobacterium spp. inhabiting the phyllosphere of plants including M. populi, M. komagatae, and M. aquaticum have been reported to have acetylene reduction activity indicating that they might possess nitrogenase activity [26]. 


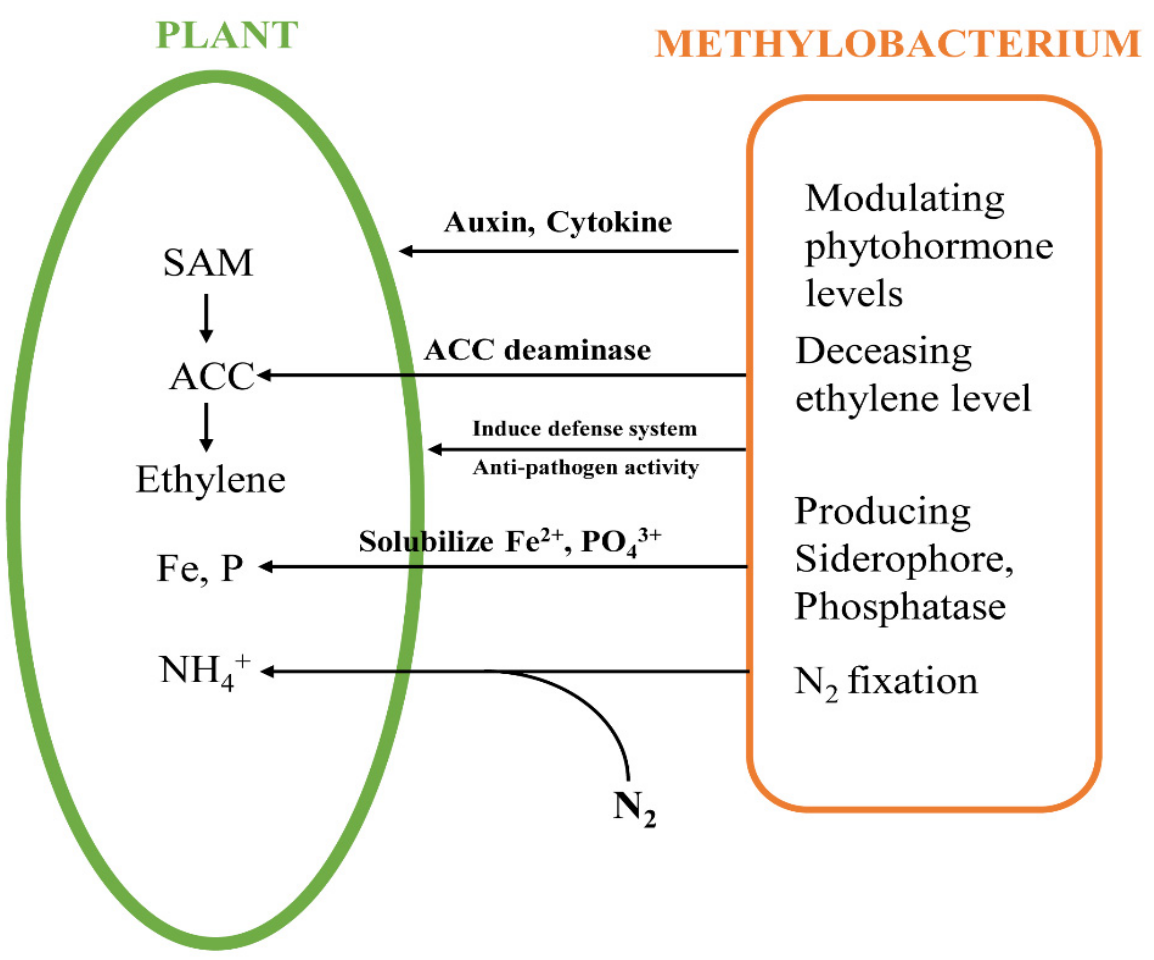

Figure 2. Mechanisms how Methylobacterium spp. promote plants growth.

Available phosphorus in soil is always limited for plant growth. Although concentrations of total phosphorus in soils are high, most inorganic phosphorus is bound to calcium, iron, and aluminum or immobilized in phytate, and cannot be utilized by plants $[45,46]$. To gain an increase in crop production, the available fixed soil phosphorus and applied phosphates need to be solubilized by phosphate-solubilizing bacteria. Methylobacterium spp. have the ability to dissolve inorganic phosphates, which in turn promotes phosphate metabolism in both microorganisms and plants [47]. Iron is important for plant growth, while much of the iron in environments is insoluble and not utilized by plants. Bacteria can produce siderophores with low-molecular-mass compounds and high affinity for iron, and accordingly solubilizing iron makes the iron available for plant uptake and promotes plant growth. Tani et al. [39] found that nearly 20\% of the strains among 190 strains of the Methylobacterium genus isolated from leaf samples of plants produced siderophores [48].

\subsection{Modulating Phytohormone Levels}

Plant hormones play important roles in plant growth and development. Methylobacterium spp. promote plant growth as biostimulators by producing phytohormones such as cytokinins and auxins and by regulating the concentration of ethylene [49]. Ethylene, an important signaling molecule in plants, can regulate cell growth and aging as well as affect the defense system. For example, $M$. oryzae produces 1-aminocyclopropane-1-carboxylate (ACC) deaminase to decrease the accumulation of ethylene by cleaving ACC, the immediate precursor of ethylene [50]. Moreover, $M$. oryzae improves photosynthesis of rice plants in salt [19]. Methylobacterium sp. CBMB12, CBMB27, CBMB15, and CBMB20 reduce ACC accumulation in tomatoes by $\sim 50 \%$, and promote tomato growth by $50 \%$ to $80 \%$. The reduced level of ethylene also induced pathogenesis-related proteins and defense enzymes, decreasing the disease symptoms of tomatoes treated with pathogens such as Agrobacterium tumefaciens and Ralstonia solanacearum [51]. Cytokinins are important growth regulators that are responsible for cell division, nutrient allocation, and photosynthetic performance. Members of the Methylobacterium genus contain miaA genes which are critical to the production of bacterial zeatin, a major type of cytokinins [13]. These Methylobacterium spp. increased the cytokinin levels of plants, improved photosynthetic capacity, and ben- 
efited the growth of plants [13]. Indole-3-acetic acid (IAA) is the main auxin in plants, playing important roles in root development [52]. Methylobacterium can produce IAA, which in turn increases plants IAA concentrations and promotes plant growth [53,54].

\subsection{Providing Protection against Plant Pathogens}

Studies showed that Methylobacterium spp. always protect plants against pathogens by influencing the microorganism community structure or defense system of the plant host [55]. Generally, bacteria induce plant systemic resistance to pathogens by releasing organic compounds or by synthesizing plant cell wall degradation enzymes [56,57]. Methylobacterium sp. IMBG290 can induce resistance in potatoes towards Pectobacterium atrosepticum by activating the antioxidant system in an inoculum density-dependent manner and by changing the endophyte community [58]. Methylobacterium extorquens DSM13060 has also been found to induce the expression of plant defense genes in pine [22]. Recently, Methylobacterium spp. was found to be able to protect plants against pathogens directly. Methylobacterium radiotolerans MAMP 4754 isolated from seeds of Combretum erythrophyllum exhibited high antibacterial and antifungal activity [24]. Vadivukkarasi et al. [59] found that 24 strains of the Methylobacterium genus isolated from the phyllosphere of gingers showed antagonistic activity against ginger pathogens including Pythium myriotylum, Macrophomina phaseolina, Fusarium oxysporum, Colletotrichum gloeosporioides, and Sclerotium rolfsii. In the future, plant pathogens might be controlled by bioways using Methylobacteia.

\section{Utilization of Plants Growth-Promoting Methylobacterium in Agriculture}

Methylobacterium showed great potential as a microbial agent in agriculture. Methylobacterium sp. 2A possessed great potential to improve potato crop yield [60]. Tomato and lettuce treated with Methylobacterium both showed increases in leaf growth rate, root growth rate, total biomass production, and seed yield and a decrease in cycle time. Agricultural companies have been working on the development of microbial agents that are sustainable and friendly to the world. For example, Indigo Agriculture has developed commercial products composed of microorganisms to improve crop yield. Indigo Wheat improves the yield of wheat by nearly $20 \%$. Indigo Cotton improves cotton yield by $10 \%$, and the increase even reaches 19\% under drought conditions. These products show great potential for wide use. Commercial microbial agents composed of only Methylobacterium to promote the growth of tomato, cotton, rice, soybean, peanut, wheat, and corn have also been developed by Newleaf Symbiotics, a company developing bioways to improve crop health and yield [61].

\section{Engineering of Crop Microbiomes}

Plant microbiomes can alter plant physiology and induce resistant systems against pathogens and tolerance mechanisms to stresses such as drought, salinity, and limited nutrients. These functions are carried by one or several microorganisms that form the "core microbiome" [62]. In plants, especially crops such as rice, corn, bean, tomato, and potato, Methylobacterium spp. carry these functions and play an important role in microbiomes $[15,51,55,63]$. Different plants grow in different environments and possess tolerance to different stresses which might depend on microbiomes to some degree [64]. Then, the transfer of these capacities to plants that lack them is important. Several ways have been developed to modify plant microbiomes by introducing microorganisms or microorganism communities including incubating microorganisms with soil, rhizosphere, seeds, or spraying microorganisms on the surface of plants $[65,66]$. The strategies conducted in recent years are reviewed below, and these strategies might help us identify novel plant growth-promoting Methylobacteria, or transfer Methylobacterium spp. or their community to plants lacking them (Figure 3). 


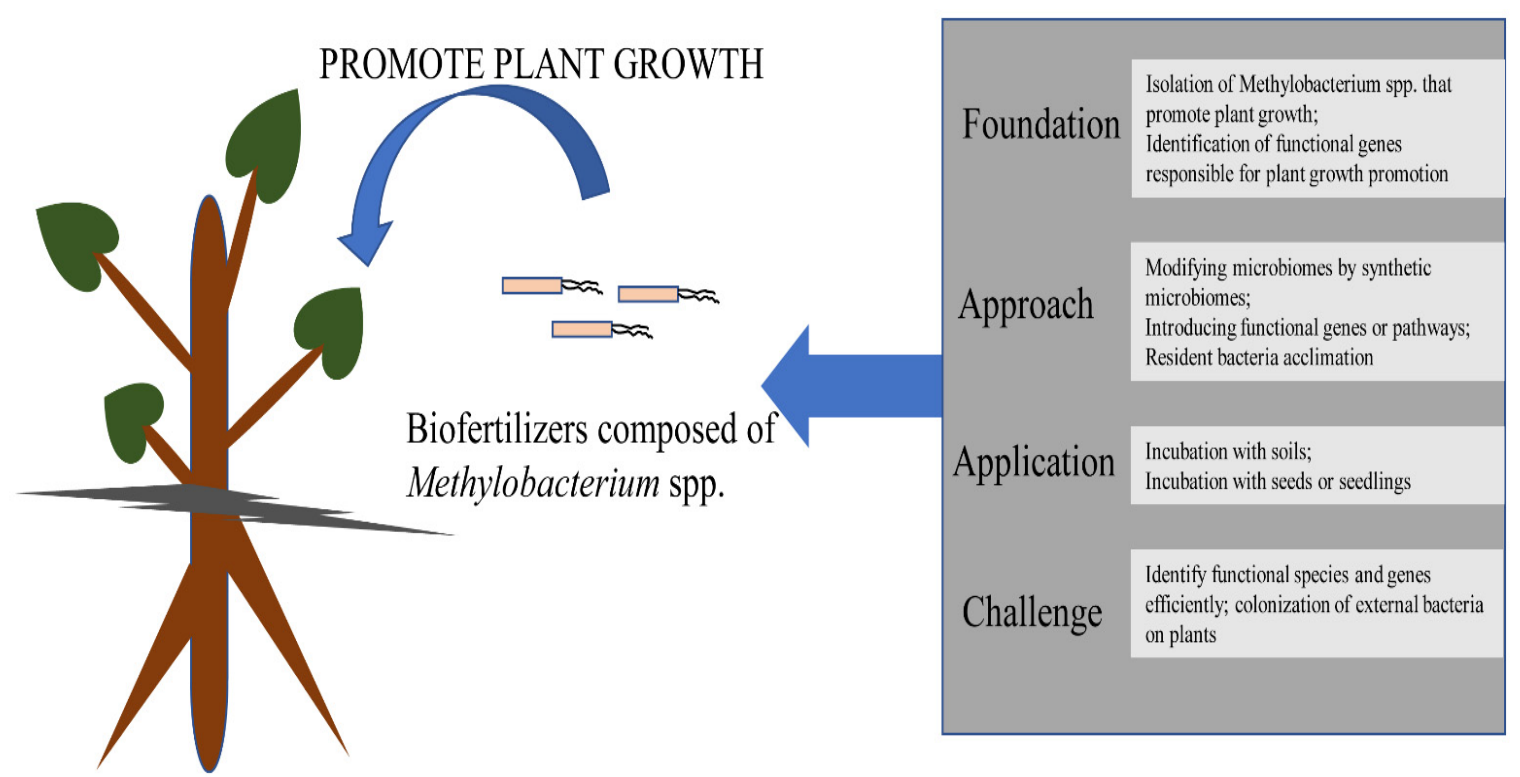

Figure 3. Strategies for bioengineering of the Methylobacteria community to promote crops growth.

\subsection{Identification of Novel Plant Growth-Promoting Methylobacteria}

Although several plant growth-promoting Methylobacteria are known to us [11,49,51,54], there might be many more Methylobacteria that are not identified but dominate the phyllosphere in many plants. It is urgent to identify more plant growth-promoting Methylobacteria due to their potential in agriculture as microbial agents. Host-mediated microbiome selection provides a good way to identify PGPB [67]. Host-mediated microbiome selection is a method that selects microbial communities indirectly through the host or features of the host that influence microbiomes $[68,69]$. The method has been used frequently to engineer plant microbiomes in the past. Panke Buisse et al. [70] used this method to select on early or late flowering of $A$. thaliana. Plants were inoculated with a starter soil community and grown in sterilized soil. At the end of each growth cycle, flowering time was measured for each replicate; then, soils of the best-performing replicates were chosen to inoculate the next generation of sterilized soils. After ten generations, microbial communities that positively influenced the host trait were selected. Previously wheat rhizosphere microbiomes were engineered in this way and improved the drought tolerance of wheat [69]. Moreover, these novel plant growth-promoting Methylobacteria could be identified and classified by combining the approach with "OMICS" technologies.

\subsection{Introduce Synthetic Microbiomes to Crops}

Methylobacterium spp. with known functions such as plant growth promotion in dry, salty, and nutrient-limited environments could be combined into simple synthetic microbiomes. Introducing the functional Methylobacterium community or species to plants lacking them forms synthetic microbiomes for plants and thus promotes plant growth, increases crop yields, and helps plants adapt to different environments. Synthetic microbiomes are usually introduced to plants in two ways: incubation with soils and incubation with seeds or seedlings.

Inoculation of external bacterial strains with rhizospheric soil can change the composition and structure of microbial communities. This method has been used to introduce species including Methylobacteria and others. When growing on soil incubated with Agrobacterium sp. 10C2, Phaseolus vulgaris was reported to show an increase in nodule number and plant biomass. The phosphorus, polyphenols, flavonoids, and total antioxidant capacity of grains also increased significantly. Agrobacterium sp. 10C2 promotes Phaseolus vulgaris growth by increasing the diversity and changing structure of microbial 
communities in the rhizosphere [65]. Methylobacteium spp. are also introduced in this way to plants, such as Terrasym 408 (developed by Newleaf Symbiotic) which enhances root development and nutrient uptake of crops.

Incubation with seeds is a popular way to introduce external functional bacteria to plants, either Methylobacteria or other bacteria. Commercial products such as Terrasym 401 for soybeans, Terrasym 402 for peanuts, and Terrasym 450 for corn have developed for seed treatment. Recently, Daniel et al. [71] reported that incubation of bacteria including Pseudomonas stutzeri E25 and Stenotrophomonas maltophilia CR71 with tomato seedlings promoted tomato growth significantly, with improvement of root biomass and photosynthetic capacity.

\section{Engineering of Methylobacterium spp. Traits to Enhance the Promotion of Plant Growth}

As the microbiomes of plants are influenced by the host, site, and environment etc., introducing external bacteria to plants might pose challenges including how to colonize new hosts and adapt to the environment. Generally, the abilities of bacteria to promote plant growth, protect plants against pathogens, and survive in drought or salty conditions are due to crucial genes or gene clusters (pathways). Introducing functional genes or pathways to resident bacteria might be better than introducing bacteria to plant lacking them as these external bacteria could not usually colonize new plant hosts or could not adapt well to new environments. As the model organism for studying C1 metabolism, M. extorquens has been engineered as a microbial cell factory to produce amino acids, organic acids, and alcohols from methanol by introducing heterologous genes and pathways [72-74]. Versatile broad-host-range vectors and insertional expression vectors have been developed for use in methylotrophs with different strengths of promoters driving gene expression [75-77]. Moreover, crucial genes or gene clusters that help bacteria adapt to the host environment or help promote host growth can be identified by using multiomics approaches and genomescale functional genomic mining [78-81]. Transposon mutation followed by sequencing (TnSeq) and clustered regularly interspaced short palindromic repeats (CRISPR)-based technologies are prominent strategies to screen genes responsible for special functions. Functional genes have been identified in $M$. extorquens by using TnSeq. Recently our colleagues developed an efficient gene mining method using CRISPR interference (CRISPRi) in M. extorquens, providing a new way to identify functional genes more efficiently [82]. Introducing these identified genes or gene clusters into resident Methylobacteria of plant host will help the resident microbiome obtain external abilities to promote plant growth.

Another choice to enhance the ability of the microbiome to promote plant growth is to improve the ability of resident Methylobacteria through random mutations achieved by treating the bacteria with UV light, chemicals, or atmosphere, and using room temperature plasma (ARTP) combined with adaptive laboratory evolution [83].

\section{Conclusions and Perspectives}

It is important to develop more microbial agents as the demand for agriculture increases significantly. The Methylobacterium genus possesses great potential to be utilized as a microbial agent to promote plant growth in different ways. The detailed mechanisms for Methylobacterium spp. to promote plant growth and how the bacteria improve crop production are not absolutely clear; therefore more research is necessary to support plantassociated microbiomes in sustainable agriculture. In the future, multiomics approaches will be applied in Methylobacterium spp. to characterize methylotrophs and understand how Methylobacterium spp. interact with plant hosts and promote their growth. More intense studies might focus on the identification of new Methylobacterium species with plant-growth-promoting abilities. With this knowledge, many Methylobacteirum spp. can be engineered to be more efficient microbial agents and to be more easily introduced to plants, especially crops lacking them. 
Author Contributions: Conceived of the presented idea, C.Z., M.-Y.W., and N.K.; developed the theory, C.Z., M.-Y.W., and L.-L.T.; writing-original draft preparation, C.Z., N.K., and L.-L.T.; writingreview and editing, C.Z., N.K., L.-L.T., and S.Y.; supervision, S.Y. All authors have read and agreed to the published version of the manuscript.

Funding: This work was supported by the National Natural Science Foundation of China (grant No. 21776149, 31900004, 22078169).

Data Availability Statement: All the data generated or analysed during this study are included in this published article.

Conflicts of Interest: The authors declare no conflict of interest.

\section{References}

1. Marc, S.R.; Matias, D.; Zurbriggen, B. The impact of synthetic biology for future agriculture and nutrition. Curr. Opin. Biotechnol. 2021, 61, 102-109.

2. Preininger, C.; Sauer, U.; Bejarano, A.; Berninger, T. Concepts and applications of foliar spray for microbial inocu-lants. Appl. Microbiol. Biotechnol. 2018, 102, 7265-7282. [CrossRef] [PubMed]

3. Kumar, M.; Tomar, R.S.; Lade, H.; Paul, D. Methylotrophic bacteria in sustainable agriculture. World J. Microbiol. Biotechnol. 2016, 32, 120. [CrossRef] [PubMed]

4. Vinod, D.; Patel, A.K.; Shukla, A.; Shukla, S.; Singh, S. Impact of continuous use of chemical fertilizer. Int. J. Eng. Res. Dev. 2012, 3, 13-16.

5. Adesemoye, A.O.; Kloepper, J.W. Plant-microbes interactions in enhanced fertilizer-use efficiency. Appl. Microbiol. Biotechnol. 2009, 85, 1-12. [CrossRef]

6. Orozco Mosqueda, M.; Rocha Granados, M.; Glick, B.R.; Santoyo, G. Microbiome engineering to improve biocontrol and plant growth-promoting mechanisms. Microbiol. Res. 2018, 208, 25-31. [CrossRef]

7. Raaijmakers, J.M.; Mazzola, M. Soil immune responses. Science 2016, 352, 1392-1393. [CrossRef]

8. Vorholt, J.A. Microbial life in the phyllosphere. Nat. Rev. Genet. 2012, 10, 828-840. [CrossRef]

9. Macey, M.C.; Pratscher, J.; Crombie, A.T.; Murrell, J.C. Impact of plants on the diversity and activity of methylotrophs in soil. Microbiome 2020, 8, 1-17. [CrossRef]

10. Madhaiyan, M.B.; Kim, Y.; Poonguzhali, S.; Kwon, S.W.; Song, M.H.; Ryu, J.H.; Go, S.J.; Koo, B.S.; Sa, T.M. Methylo-bacterium oryzae SP. Nov., an aerobic, pink-pigmented, facultatively methylotrophic, 1-aminocyclopropane-1-carboxylate deaminaseproducing bacterium isolated from rice. Int. J. Syst. Evol. Microbiol. 2007, 57, 326-331. [CrossRef] [PubMed]

11. Jourand, P.; Giraud, E.; Béna, G.; Sy, A.; Willems, A.; Gillis, M.; Dreyfus, B.; De Lajudie, P. Methylobacterium nodulans sp. nov., for a group of aerobic, facultatively methylotrophic, legume root-nodule-forming and nitrogen-fixing bacteria. Int. J. Syst. Evol. Microbiol. 2004, 54, 2269-2273. [CrossRef]

12. Jorge, G.L.; Kisiala, A.; Morrison, E.; Aoki, M.; Nogueira, A.P.O.; Emery, R.N. Endosymbiotic Methylobacterium oryzae mitigates the impact of limited water availability in lentil (Lens culinaris Medik.) by increasing plant cytokinin levels. Environ. Exp. Bot. 2019, 162, 525-540. [CrossRef]

13. Chanratana, M.; Han, G.H.; Melvin Joe, M.; Roy Choudhury, A.; Sundaram, S.; Halim, M.A.; Sa, T. Evaluation of chitosan and alginate immobilized Methylobacterium oryzae CBMB20 on tomato plant growth. Arch. Agron. Soil Sci. 2018, 64, 1489-1502. [CrossRef]

14. Tani, A.; Sahin, N.; Fujitani, Y.; Kato, A.; Sato, K.; Kimbara, K. Methylobacterium species promoting rice and barley growth and interaction specificity revealed with whole-cell matrix-assisted laser desorption / ionization-time-of-flight mass spectrometry (Maldi-tof/MS) analysis. PLoS ONE 2015, 10, e0129509. [CrossRef]

15. Fedorov, D.N.; Ekimova, G.A.; Doronina, N.V.; Trotsenko, Y.A. 1-aminocyclopropane-1-carboxylate (ACC) Deam-inases from methylobacterium radiotolerans and methylobacterium nodulans with higher specificity for ACC. FEMS Microbiol. Lett. 2013, 343, 70-76. [CrossRef]

16. Bahulikar, R.A.; Torres-Jerez, I.; Worley, E.; Craven, K.; Udvardi, M.K. Diversity of nitrogen-fixing bacteria associated with switchgrass in the native tallgrass prairie of Northern Oklahoma. Appl. Environ. Microbiol. 2014, 80, 5636-5643. [CrossRef]

17. Chanratana, M.; Han, G.H.; Choudhury, A.R.; Sundaram, S.; Halim, M.A.; Krishnamoorthy, R.; Kang, Y.; Sa, Y. Assessment of methylobacterium oryzae cbmb20 aggregates for salt tolerance and plant growth promoting characteristics for bio-inoculant development. AMB Express 2017, 7, 208. [CrossRef]

18. Chatterjee, P.; Kanagendran, A.; Samaddar, S.; Pazouki, L.; Sa, T.-M.; Niinemets, Ü. Methylobacterium oryzae CBMB20 influences photosynthetic traits, volatile emission and ethylene metabolism in Oryza sativa genotypes grown in salt stress conditions. Planta 2019, 249, 1903-1919. [CrossRef] [PubMed]

19. Kwak, M.-J.; Jeong, H.; Madhaiyan, M.; Lee, Y.; Sa, T.-M.; Oh, T.K.; Kim, J.F. Genome information of methylobacterium oryzae, a plant-probiotic methylotroph in the phyllosphere. PLoS ONE 2014, 9, e106704. [CrossRef]

20. Laukel, M.; Rossignol, M.; Borderies, G.; Völker, U.; Vorholt, J.A. Comparison of the proteome of Methylobacterium extorquens AM1 grown under methylotrophic and nonmethylotrophic conditions. Proteomics 2004, 4, 1247-1264. [CrossRef] 
21. Koskimäki, J.J.; Pirttilä, A.M.; Ihantola, E.-L.; Halonen, O.; Frank, A.C. The intracellular scots pine shoot symbiont methylobacterium extorquens dsm13060 aggregates around the host nucleus and encodes eukaryote-like proteins. mBio 2015, 6, e00039-15. [CrossRef]

22. Madhaiyan, M.; Poonguzhali, S.; Lee, H.S.; Hari, K.; Sundaram, S.P.; Sa, T.M. Pink-pigmented facultative methylotrophic bacteria accelerate germination, growth and yield of sugarcane clone Co86032 (Saccharum officinarum L.). Biol. Fertil. Soils 2005, 41, 350-358. [CrossRef]

23. Rafique, M.; Naveed, M.; Mustafa, A.; Akhtar, S.; Munawar, M.; Kaukab, S.; Ali, H.M.; Siddiqui, M.H.; Salem, M.Z.M. The combined effects of gibberellic acid and rhizobium on growth, yield and nutritional status in chickpea (Cicer arietinum L.). Agronomy 2021, 11, 105. [CrossRef]

24. Priya, M.; Kumutha, K.; Senthilkumar, M. Impact of bacterization of rhizobium and methylobacterium radiotolerans on germination and survivability in groundnut seed. Int. J. Curr. Microbiol. Appl. Sci. 2019, 8, 394-405. [CrossRef]

25. Madhaiyan, M.; Alex, T.H.H.; Ngoh, S.T.; Prithiviraj, B.; Ji, L. Leaf-residing Methylobacterium species fix nitrogen and promote biomass and seed production in Jatropha curcas. Biotechnol. Biofuels 2015, 8, 1-14. [CrossRef] [PubMed]

26. Schauer, S.; Kutschera, U. A novel growth-promoting microbe, methylobacterium funariae SP. Nov., isolated from the leaf surface of a common moss. Plant Signal. Behav. 2013, 6, 510-515. [CrossRef]

27. Madhaiyan, M.; Poonguzhali, S.; Kwon, S.W.; Sa, T.M. Methylobacterium phyllosphaerae SP. Nov., a pink-pigmented, facultative methylotroph from the phyllosphere of rice. Int. J. Syst. Evol. Microbiol. 2009, 59, 22-27. [CrossRef] [PubMed]

28. Firdous, J.; Lathif, N.A.; Mona, R.; Muhamad, N. Endophytic bacteria and their potential application in agriculture. Indian J. Agric. Res. 2019, 53, 1-7.

29. Sy, A.; Giraud, E.; Jourand, P.; Garcia, N.R.; Willems, A.; De Lajudie, P.; Prin, Y.; Neyra, M.; Gillis, M.; Boivin-Masson, C.; et al. Methylotrophic methylobacteriumbacteria nodulate and fix nitrogen in symbiosis with legumes. J. Bacteriol. 2001, 183, 214-220. [CrossRef]

30. Finkel, O.M.; Burch, A.Y.; Elad, T.; Huse, S.M.; Lindow, S.E.; Post, A.F.; Belkin, S. Distance-decay relationships par-tially determine diversity patterns of phyllosphere bacteria on tamrix trees across the sonoran desert. Appl. Environ. Microbiol. 2012, 78, 6187-6693. [CrossRef]

31. Kembel, S.W.; O'Connor, T.K.; Arnold, H.K.; Hubbell, S.P.; Wright, S.J.; Green, J.L. Relationships between phyllo-sphere bacterial communities and plant functional traits in a neotropical forest. Proc. Natl. Acad. Sci. USA 2014, 111, 13715-13720. [CrossRef] [PubMed]

32. Knief, C.; Frances, L.; Vorholt, J.A. Competitiveness of diverse methylobacterium strains in the phyllo-sphere of arabidopsis thaliana and identification of representative models, including M. Extorquens Pa1. Microb. Ecol. 2010, 60, 440-452. [CrossRef] [PubMed]

33. Sy, A.; Timmers, A.C.; Knief, C.; Vorholt, J.A. Methylotrophic metabolism is advantageous for methylobacterium ex-torquens during colonization of medicago truncatula under competitive conditions. Appl. Environ. Microbiol. 2005, 71, 7245-7252. [CrossRef] [PubMed]

34. Naveed, M.; Ramzan, N.; Mustafa, A.; Samad, A.; Niamat, B.; Yaseen, M.; Ahmad, Z.; Hasanuzzaman, M.; Sun, N.; Shi, W.; et al. Alleviation of salinity induced oxidative stress in chenopodium quinoa by fe biofortification and biochar-Endophyte interaction. Agronomy 2020, 10, 168. [CrossRef]

35. Yoshida, S.; Hiradate, S.; Koitabashi, M.; Kamo, T.; Tsushima, S. Phyllosphere methylobacterium bacteria contain UVA-absorbing compounds. J. Photochem. Photobiol. B Biol. 2017, 167, 168-175. [CrossRef]

36. Rossetto, P.B.; Dourado, M.N.; Quecine, M.C.; Andreote, F.D.; Araújo, W.L.; Azevedo, J.L.; Pizzirani-Kleiner, A.A. Specific plant induced biofilm formation in Methylobacterium species. Braz. J. Microbiol. 2011, 42, 878-883. [CrossRef]

37. Doronina, N.V.; Gogleva, A.A.; Trotsenko, Y.A. Methylophilus glucosoxydans sp. nov., a restricted facultative methylotroph from rice rhizosphere. Int. J. Syst. Evol. Microbiol. 2012, 62, 196-201. [CrossRef]

38. Iguchi, H.; Yurimoto, H.; Sakai, Y. Interactions of methylotrophs with plants and other heterotrophic bacteria. Microorganisms 2015, 3, 137-151. [CrossRef] [PubMed]

39. Tani, A.; Sahin, N.; Matsuyama, Y.; Enomoto, T.; Nishimura, N.; Yokota, A.; Kimbara, K. High-throughput identification and screening of novel methylobacterium species using whole-cell maldi-tof/MS analysis. PLoS ONE 2012, 7, e40784. [CrossRef]

40. Müller, D.B.; Schubert, O.T.; Röst, H.; Aebersold, R.; Vorholt, J.A. Systems-level proteomics of two ubiquitous leaf commensals reveals complementary adaptive traits for phyllosphere colonization. Mol. Cell. Proteom. 2016, 15, 3256-3269. [CrossRef]

41. Roodi, D.; Millner, J.P.; McGill, C.; Johnson, R.D.; Jauregui, R.; Card, S.D. Methylobacterium, a major component of the culturable bacterial endophyte community of wild Brassica seed. PeerJ 2020, 8, e9514. [CrossRef] [PubMed]

42. Khan, N.; Bano, A. Role of plant growth promoting rhizobacteria and Ag-nano particle in the bioremediation of heavy metals and maize growth under municipal wastewater irrigation. Int. J. Phytoremediat. 2016, 18, 211-221. [CrossRef] [PubMed]

43. Laforest-Lapointe, I.; Messier, C.; Kembel, S.W. Host species identity, site and time drive temperate tree phyllosphere bacterial community structure. Microbiome 2016, 4, 1-10. [CrossRef]

44. Menna, P.; Hungria, M.; Barcellos, F.G.; Bangel, E.V.; Hess, P.N.; Martínez-Romero, E. Molecular phylogeny based on the 16S rRNA gene of elite rhizobial strains used in Brazilian commercial inoculants. Syst. Appl. Microbiol. 2006, 29, 315-332. [CrossRef]

45. Peyraud, R.; Schneider, K.; Kiefer, P.; Massou, S.; Vorholt, J.A.; Portais, J.C. Genome-scale reconstruction and system level investigation of the metabolic network of Methylobacterium extorquens AM1. BMC Syst. Biol. 2011, 5, 1-22. [CrossRef] [PubMed] 
46. Lim, B.L.; Yeung, P.; Cheng, C.; Hill, J.E. Distribution and diversity of phytate-mineralizing bacteria. ISME J. 2007, 1, 321-330. [CrossRef]

47. Rodríguez, H.; Fraga, R.; Gonzalez, T.; Bashan, Y. Genetics of phosphate solubilization and its potential applications for improving plant growth-promoting bacteria. Plant Soil 2006, 287, 15-21. [CrossRef]

48. Agafonova, N.V.; Kaparullina, E.N.; Doronina, N.V.; Trotsenko, Y.A. Phosphate-solubilizing activity of aerobic methylobacteria. Microbiology 2013, 82, 864-867. [CrossRef]

49. Hoppe, T.; Peters, K.; Schmidt, F. Methylobacterium bullatum sp. nov., a methylotrophic bacterium isolated from Funaria hygrometrica. Syst. Appl. Microbiol. 2011, 34, 482-486. [CrossRef] [PubMed]

50. Madhaiyan, M.; Poonguzhali, S.; Sa, T. Characterization of 1-aminocyclopropane-1-carboxylate (ACC) deaminase containing Methylobacterium oryzae and interactions with auxins and ACC regulation of ethylene in canola (Brassica campestris). Planta 2007, 226, 867-876. [CrossRef] [PubMed]

51. Yim, W.; Seshadri, S.; Kim, K.; Lee, G.; Sa, T. Ethylene emission and PR protein synthesis in ACC deaminase producing methylobacterium spp. Inoculated tomato plants (Lycopersicon esculentum mill.) Challenged with ralstonia sola-nacearum under greenhouse conditions. Plant Physiol. Biochem. 2013, 67, 95-104. [CrossRef]

52. Kousar, B.; Bano, A.; Khan, N. PGPR Modulation of Secondary Metabolites in Tomato Infested with Spodoptera litura. Agronomy 2020, 10, 778. [CrossRef]

53. Ivanova, E.G.; Doronina, N.V.; Trotsenko, I.A. Aerobic methylobacteria are capable of synthesizing аuхins. Микробиология 2001, 70, 452-458.

54. Madhaiyan, M.; Poonguzhali, S.; Ryu, J.; Sa, T. Regulation of ethylene levels in canola (Brassica campestris) by 1-aminocyclopropane-1-carboxylate deaminase-containing Methylobacterium fujisawaense. Planta 2006, 224, $268-278$. [CrossRef] [PubMed]

55. Ardanov, P.; Sessitsch, A.; Häggman, H.; Kozyrovska, N.; Pirttilä, A.M. Methylobacterium-induced endophyte community changes correspond with protection of plants against pathogen attack. PLoS ONE 2012, 7, e46802. [CrossRef]

56. Madhaiyan, M.; Reddy, B.V.S.; Anandham, R.; Senthilkumar, M.; Poonguzhali, S.; Sundaram, S.P.; Sa, T. Plant growth-promoting methylobacterium induces defense responses in groundnut (Arachis hypogaea L.) compared with rot pathogens. Curr. Microbiol. 2006, 53, 270-276. [CrossRef] [PubMed]

57. Lee, H.S.; Madhaiyan, M.; Kim, C.W.; Choi, S.J.; Chung, K.Y.; Sa, T.M. Physiological enhancement of early growth of rice seedlings (Oryza sativa L.) by production of phytohormone of N2-fixing methylotrophic isolates. Biol. Fertil. Soils 2006, 42, 402-408. [CrossRef]

58. Ardanov, P.; Ovcharenko, L.; Zaets, I.; Kozyrovska, N.; Pirttila, A.M. Endophytic bacteria enhancing growth and disease resistance of potato (Solanum tuberosum L.). Biol. Control 2011, 56, 43-49.

59. Vadivukkarasi, P.; Bhai, R.S. Phyllosphere-associated methylobacterium: A potential biostimulant for ginger (Zin-giber officinale rosc.) Cultivation. Arch. Microbiol. 2020, 202, 369-375. [CrossRef]

60. Grossi, C.E.M.; Fantino, E.; Serral, F.; Zawoznik, M.S.; Porto, D.A.F.D.; Ulloa, R.M. Methylobacterium SP. 2a is a plant growthpromoting rhizobacteria that has the potential to improve potato crop yield under adverse conditions. Front. Plant Sci. 2020, 11, 71. [CrossRef]

61. Laurita, T.; Kerovuo, J. Plant microbiome innovation: M-trophs. Ind. Biotechnol. 2018, 14, 129-133. [CrossRef]

62. Aziz, M.Z.; Yaseen, M.; Abbas, T.; Naveed, M.; Mustafa, A.; Hamid, Y.; Saeed, Q.; XU, M.G. Foliar application of micronutrients enhances crop stand, yield and the biofortification essential for human health of different wheat culti-vars. J. Integrat. Agric. 2019, 18, 1369-1378. [CrossRef]

63. Yim, W.J.; Chauhan, P.S.; Madhaiyan, M.; Tipayno, S.C.; Sa, T.M. Plant growth promontory attributes by 1-aminocyclopropane-1carboxylate_(ACC) Deaminase producing methylobacterium oryzae strains isolated from rice. In Proceedings of the World Congress of Soil Science, Soil Solutions for a Changing World, Brisbane, Austrailia, 1-6 August 2010.

64. Song, C.; Zhu, F.; Carrión, V.J.; Cordovez, V. Beyond plant microbiome composition: Exploiting microbial functions and plant traits via integrated approaches. Front. Bioeng. Biotechnol. 2020, 8, 896. [CrossRef]

65. Khan, N.; Bano, A.; Curá, J.A. Role of beneficial microorganisms and salicylic acid in improving rainfed agriculture and future food safety. Microorganisms 2020, 8, 1018. [CrossRef] [PubMed]

66. Pavlova, A.S.; Leontieva, M.R.; Smirnova, T.A.; Kolomeitseva, G.L.; Netrusov, A.I.; Tsavkelova, E.A. Colonization strategy of the endophytic plant growth-promoting strains of pseudomonas fluorescens and klebsiella oxytoca on the seeds, seedlings and roots of the epiphytic orchid, dendrobium nobile lindl. J. Appl. Microbiol. 2017, 123, 123. [CrossRef] [PubMed]

67. Mueller, U.; Sachs, J. Engineering microbiomes to improve plant and animal health. Trends Microbiol. 2015, 23 , 606-617. [CrossRef] [PubMed]

68. Wright, R.J.; Gibson, M.I.; Christie-Oleza, J.A. Understanding microbial community dynamics to improve optimal microbiome selection. Microbiome 2019, 7, 1-14. [CrossRef] [PubMed]

69. Naveed, M.; Mustafa, A.; Azhar, S.Q.T.A.; Kamran, M.; Zahir, Z.A.; Núñez-Delgado, A. Burkholderia phy-tofirmans PsJN and tree twigs derived biochar together retrieved $\mathrm{Pb}$-induced growth, physiological and biochemical dis-turbances by minimizing its uptake and translocation in mung bean (Vigna radiata L.). J. Environ. Manag. 2020, 257, 109974. [CrossRef]

70. Panke-Buisse, K.; Poole, A.C.; Goodrich, J.K.; Ley, R.E.; Kao-Kniffin, J. Selection on soil microbiomes reveals re-producible impacts on plant function. ISME J. 2015, 9, 980-989. [CrossRef] 
71. Daniel, R.S.; Elizabeth, Z.S.; Miguel, C.P.; Ma del Carmen, R.G.; Lourdes, M.R.; Gustavo, S. Pseudomonas stutzeri e25 and stenotrophomonas maltophilia cr71 endophytes produce antifungal volatile organic compounds and exhibit additive plant growth-promoting effects. Biocatal. Agric. Biotechnol. 2018, 13, 46-52.

72. Hu, B.; Yang, Y.-M.; Beck, D.A.C.; Wang, Q.-W.; Chen, W.-J.; Yang, J.; Lidstrom, M.E.; Yang, S. Comprehensive molecular characterization of Methylobacterium extorquens AM1 adapted for 1-butanol tolerance. Biotechnol. Biofuels 2016, 9, 84. [CrossRef]

73. Yang, Y.M.; Chen, W.I.; Yang, J.; Zhou, Y.M.; Hu, B.; Zhang, M.; Zhu, L.P.; Wang, G.Y.; Yang, S. Production of 3-hydroxypropionic acid in engineered methylobacterium extorquens am1 and its reassimilation through a reductive route. Microb. Cell Fact. 2017, 16, 179. [CrossRef] [PubMed]

74. Li, X.; Wu, B.; Zhou, K.; Jiang, C.; Shen, P. Deletion of gene gnd encoding 6-phosphogluconate dehydrogenase promotes l-serine biosynthesis in a genetically engineered strain of Methylobacterium sp. MB200. Biotechnol. Lett. 2019, 41, 69-77. [CrossRef] [PubMed]

75. Marx, C.J.; Lidstrom, M.E. Development of improved versatile broad-host-range vectors for use in methylotrophs and other Gram-negative bacteria the GenBank accession numbers for the sequences reported in this paper are AF327711, AF327712, AF327713, AF327714, AF327715, AF327716, AF327717, AF327718, AF327719 and AF327720. Microbiology 2001, 147, $2065-2075$. [CrossRef] [PubMed]

76. Marx, C.J.; Lidstrom, M.E. Development of an insertional expression vector system for Methylobacterium extorquens AM1 and generation of null mutants lacking mtdA and/or fch. Microbiology 2004, 150, 9-19. [CrossRef] [PubMed]

77. Von Borzyskowski, L.S.; Remus-Emsermann, M.; Weishaupt, R.; Vorholt, J.A.; Erb, T.J. A set of versatile brick vectors and promoters for the assembly, expression, and integration of synthetic operons inmethylobacterium extorquensam 1 and other alphaproteobacteria. ACS Synth. Biol. 2015, 4, 430-443. [CrossRef] [PubMed]

78. Saeed, Z.; Naveed, M.; Imran, M.; Bashir, M.A.; Sattar, A.; Mustafa, A.; Hussain, A.; Xu, M. Combined use of Enterobacter sp. MN17 and zeolite reverts the adverse effects of cadmium on growth, physiology and antioxidant activity of Brassica napus. PLoS ONE 2019, 14, e0213016. [CrossRef]

79. Yang, S.; Sadilek, M.; Lidstrom, M.E. Streamlined pentafluorophenylpropyl column liquid chromatography-tandem quadrupole mass spectrometry and global 13C-labeled internal standards improve performance for quantitative metabolomics in bacteria. J. Chromatogr. A 2010, 1217, 7401-7410. [CrossRef]

80. Vuilleumier, S.; Chistoserdova, L.; Lee, M.-C.; Bringel, F.; Lajus, A.; Zhou, Y.; Gourion, B.; Barbe, V.; Chang, J.; Cruveiller, S.; et al. Methylobacterium genome sequences: A reference blueprint to investigate microbial metabolism of $\mathrm{c}$ compounds from natural and industrial sources. PLoS ONE 2009, 4, e5584. [CrossRef]

81. Khan, N.; Bano, A.; Zandi, P. Effects of exogenously applied plant growth regulators in combination with PGPR on the physiology and root growth of chickpea (Cicer arietinum) and their role in drought tolerance. J. Plant Interact. 2018, 13, 239-247. [CrossRef]

82. Mo, X.H.; Zhang, H.; Wang, T.M.; Zhang, C.; Zhang, C.; Xing, X.H.; Yang, S. Establishment of Crispr Interference in Methylorubrum Extorquens and Application of Rapidly Mining a New Phytoene Desaturase Involved in Carotenoid Bio-synthesis. Appl. Microbiol. Biotechnol. 2020, 104, 4515-4532. [CrossRef] [PubMed]

83. Cui, L.-Y.; Wang, S.-S.; Guan, C.-G.; Liang, W.-F.; Xue, Z.-L.; Zhang, C.; Xing, X.-H. Breeding of methanol-tolerant methylobacterium extorquens am 1 by atmospheric and room temperature plasma mutagenesis combined with adaptive laboratory evolution. Biotechnol. J. 2018, 13, 1700679. [CrossRef] [PubMed] 